Check for updates

The BMJ

kabbasi@bmi.com Follow Kamran on Twitter @KamranAbbasi] Cite this as: BMJ2020;370:m3093 http://dx.doi.org/10.1136/bmj.m3093 Published: 06 August 2020

\section{Behavioural fatigue: a flawed idea central to a flawed pandemic response}

\section{Kamran Abbasi executive editor}

What is behavioural fatigue? Nobody really knows, but it is something we should be acutely aware of because it is a major reason why the UK delayed implementing lockdown, even though the best research indicates that swift and strict social distancing measures will limit the incidence of covid-19 infections. ${ }^{12}$

That delay in lockdown helped contribute to England achieving the highest excess deaths in Europe, as calculated by the Office of National Statistics. ${ }^{3}$ The full burden of long term complications in people who survive is yet to be calculated. ${ }^{4}$ It is not as if behavioural fatigue is a concept recognised by behavioural experts. Susan Michie and Robert West describe it as "an ill-defined new term that had no basis in behavioural science." 5

Greater prominence of behavioural science is a positive development. Much nonsense is talked in the name of behaviour, from how it will end obesity to how it renders face masks ineffective thanks to risk compensation. ${ }^{67}$ The sector is short of research funding, a neglect that fits with a flawed emphasis on treatment over prevention. Behavioural science is transdisciplinary and is central to tackling this and any future pandemic-and the greater threat of climate change. ${ }^{8}$

Ironically, the concept of behavioural fatigue is said to be rooted in the evidence. ${ }^{9}$ But what evidence? If there's no evidence for it then how did the government follow the science? The behavioural subcommittee advising SAGE and the government's behavioural nudge unit deny introducing this concept. ${ }^{10}$ Perhaps David Halpern, the head of the nudge unit, or Chris Whitty, England's chief medical officer, should explain why behavioural fatigue came to be such common parlance and so influential?

Behavioural interventions can succeed only if the rest of the system operates optimally. But recent experiences from Leicester and Sandwell tell us that the promised world class systems of testing and tracing are bucket class. ${ }^{11}{ }^{12}$ Local leaders are losing confidence in the government's ability to deliver them and communicate effectively. With new research casting doubt on the reliability of serology tests for covid-19 at the point of care, the fundamental pillars of a pandemic response-namely, test, trace, and isolate-are wobbly at best. ${ }^{13}$ None of this provides any confidence in the government's proposed "radical shake up" of the NHS. ${ }^{14}$

Nor does divergence in national strategies rebuild public trust that was destroyed not by behavioural fatigue but by Dominic Cummings, England's most senior government adviser. ${ }^{15}$ Scotland wants all four UK nations to follow an elimination strategy, aiming for "zero covid." Northern Ireland has already committed, but England, persistent in its flawed response, is content for the virus to hover around, to hope it doesn't overwhelm health services, and to play "whack-a-mole” with local outbreaks.

1 Islam N, Sharp SJ, Chowell G, etal. Physical distancing interventions and incidence of coronavirus disease 2019: natural experiment in 149 countries. BMJ 2020;370:m2743. doi: 10.1136/bmj.m2743 pmid: 32669358

May T. Lockdown-type measures look effective against covid-19. BMJ2020;370:m2809. doi: 10.1136/bmj.m2809 pmid: 32669280

Griffin S. Covid-19: England had worst excess mortality in Europe in April. BMJ2020;370:m3058. doi: 10.1136/bmj.m3058 pmid: 32737032

Fraser E. Long term respiratory complications of covid-19. BMJ2020;370:m3001. doi: 10.1136/bmj.m3001 pmid: 32747332

Michie S, West R. Behavioural, environmental, social, and systems interventions against covid-19. BMJ2020;370:m2982. doi: 10.1136/bmj.m2982 pmid: 32723732 Kar P. Partha Kar: Our approach to tackling obesity needs rethinking. BMJ2020;370:m3034.

Mantzari E, Rubin GJ, Marteau TM. Is risk compensation threatening public health in the covid-19 pandemic?BMJ2020;370:m2913. doi: 10.1136/bmj.m2913 pmid: 32713835

8 Salas RN. Lessons from the covid-19 pandemic provide a blueprint for the climate emergency. BMJ2020;370:m3067.

9 Wood V. Government delayed lockdown over fears of “behavioural fatigue”-but their own scientists don't agree it exists. Independent. 30 Jul 2020. https://www.independent.co.uk/news/uk/home-news/coronavirus-behavioural-fatigue-uk-lockdown-delay-science-chris-witty-robert-west-a9644971.html.

10 Behavioural Insights Team. Behavioural Insights, the WHO and COVID-19. 21 May 2020. https://www.bi.team/blogs/behavioural-insights-the-who-and-covid 19.

11 Limb M. Covid-19: Sandwell Council in West Midlands sets up contract tracing, citing failures of national scheme. BMJ2020;370:m3065. doi: 10.1136/bmj.m3065 pmid: 32737052

12 Wise J. Leicester lockdown: could better data have prevented it?BM/2020;370:m3028doi: 10.1136/bmj.m3028.

13 Lisboa Bastos M, Tavaziva G, Abidi SK, etal. Diagnostic accuracy of serological tests for covid-19: systematic review and meta-analysis. BM/2020;370:m2516. doi: 10.1136/bmj.m2516 pmid: 32611558

14 Edwards N. Plans to shake-up the NHS have a central flaw. BMJ Opinion. 28 Jul 2020. https://blogs.bmi.com/bmi/2020/07/28/nigel-edwards-plans-to-shakeup-the-nhs-have-a-central-flaw.

15 Torjesen I. Covid-19: Should the UK be aiming for elimination?BMJ2020;370:m3071. doi: 10.1136/bmj.m3071 pmid: 32747404 